\title{
First record of Androcorys pusillus (Orchidaceae) from Mt. Baekdu
}

\author{
Jungsim Lee, Soo-Nam Kim ${ }^{1}$ and Muyeol Kim* \\ Department of Biological Sciences, Chonbuk National University, Jeonju 561-756, Korea \\ ${ }^{1}$ Namyangju Songla Elementary School, Namyangju 472-845, Korea \\ (Received 5 November 2012; Revised 20 November 2012; Accepted 3 December 2012) \\ 백두산의 미기록 식물: 수림란(난초과) \\ 이정심 · 김수남 ${ }^{1} \cdot$ 김무열* \\ 전북대학교 자연과학대학 생명과학과, ${ }^{1}$ 남양주 송라초등학교
}

\begin{abstract}
Androcorys pusillus (Ohwi \& Fukuy.) Masam. (Orchidaceae) was first found from Mt. Baekdu of the Korean peninsular and was known to distribute from Taiwan and Japan. This species is distinguished from the related taxa by its denticulated sepal margin, petal width which is as broad as dorsal sepal, and larger bract size.
\end{abstract}

Keywords: Androcorys pusillus, Orchidaceae, Mt. Baekdu

\begin{abstract}
적 요: 수림란 Androcorys pusillus (Ohwi \& Fukuy.) Masam.은 그동안 일본과 대만에만 분포하는 것으로 알 려진 난초과 식물로 백두산에서 처음으로 발견되었다. 수림란은 꽃받침의 가장자리에 거치가 있고, 꽃잎이 중앙 꽃받침처럼 넓으며, 포가 큰 특징을 가져 근연종과 뚜렷이 구별된다.
\end{abstract}

주요어: 수림란, 난초과, 백두산

The genus Androcorys Schlechter (Orchidaceae) consists of approximately 6 species and is distributed from the Himalayas through S. China to Japan (Chen et al., 2009).

The genus Androcorys is characterized by 1 leaf, 1 anther, and unlobed lip petal without spur (Liu and $\mathrm{Su}, 1978$ ). Six taxa of Androcorys are distributed in China (Chen et al., 2009). All taxa have a rare occurrence in China.

Baekdusan (Mt. Baekdu) is an active volcanic mountain on the border between Korea and Manchuria, and has a large crater lake called Heaven Lake (Korean name: Cheonji) with a circumference of 12-14 km and an average depth of $213 \mathrm{~m}$ (Lee, 1991). It is also the highest mountain (2,744 $\mathrm{m}$ ) on the Korean peninsula and in Manchuria. The mountain is the source of Tumen, Yalu and Songhua rivers. Mt. Baekdu contains about 1,500 species of vascular plants, of which 11

\footnotetext{
*Author for correspondence: mykim@jbnu.ac.kr

http://www.pltaxa.or.kr

Copyright (C) 2013 the Korean Society of Plant Taxonomists
}

angiosperms are endemic (Kim, 2004).

In 2009, the authors first discovered Androcorys pusillus (Ohwi \& Fukuy.) Masam. on Mt. Baekdu. It forms a small population of thirty individuals at $1,700 \mathrm{~m}$ altitude in the Underground Forest (Korean name: Jihasanrim) area of Mt. Baekdu. This taxon was previously reported in Taiwan and Japan, where its occurrence is rare (Maekawa, 1971; Liu and Su, 1978; Ohwi, 1984; Kitamura et al., 1986). The species shares several characteristics with its related taxa, but it can be distinguished based on denticulated sepal margin, petal width which is as broad as dorsal sepal, larger bract size, etc. The voucher specimen is preserved in the herbarium of Chonbuk National University (JNU).

Androcorys pusillus (Ohwi \& Fukuy.) Masam., Hokuriku J. Bot. 12: 88 (1963). Figs. 1-2.

Herminium pusillum Ohwi \& Fukuy., Bot. Mag. (Tokyo) 48: 430 (1934).

Androcorys japonensis F. Maek., J. Jap. Bot. 12: 96 (1936). Androcorys pusilla (Ohwi \& Fukuy.) Liu \& Su, Flora of 


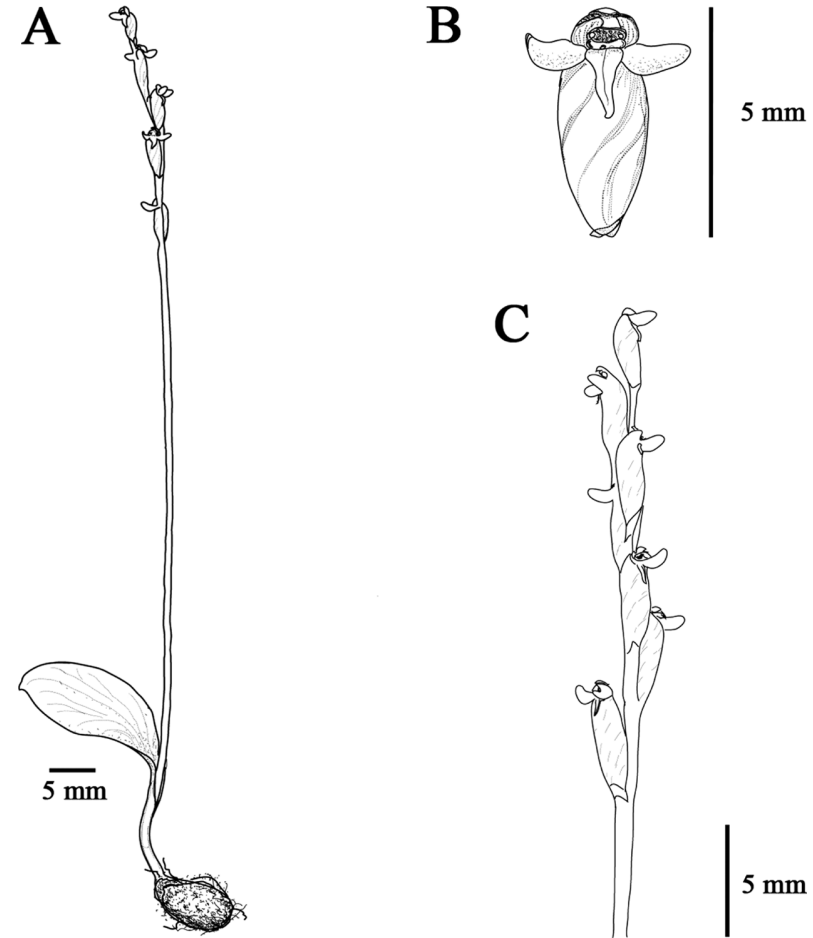

Fig. 1. Androcorys pusillus (Ohwi \& Fukuy.) Masam. A. Adult plant; B. Flower; C. Inflorescence.

Taiwan 5: 873 (1978).

\section{Korean name: Su-rim-ran 수림란}

Herbs perennial, 10-18 cm tall, glabrous. Tuber ovoid, 5-7 $\mathrm{mm}$ in diam. Stem erect, slender, 1 leaf near the base, with 3-4 scales. Leaves ovate, $1.5-4 \times 0.8-1.5 \mathrm{~cm}$, apex obtuse. Raceme terminal, erect, 10-15 cm long, 4-8 flowered; bracts subcodate, 1-2 mm long, glabrous; pedicel 1-2 mm long, glabrous. Dorsal sepal erect, greenish, ovate, $1 \times 0.5 \mathrm{~mm}$, margin irregularly denticulate; lateral sepals spreading, greenish, oblong, 1-2 $\times$ 0.8-1 mm, margin denticulate. Petals brownish, elliptic, 1-1.5 $\times$ 0.6-1 mm, 1-veined, base cuneate, margin entire, apex rounded; lip unlobed, without spur, brownish, ligulate, 1.5-2 × 0.8-1.2 $\mathrm{mm}$, base dilated, apex obtuse, glabrous. Ovary cylindrical, 4$5 \times 2-2.5 \mathrm{~mm}$; column short. Flowering July.

Voucher Specimen: Mt. Baekdu. July 19, 2009. MKA 20090401. Herbarium of Chonbuk National University (JNU).

Distribution: Korea (Mt. Baekdu), Japan (HonshuYatsugatake), Taiwan (Mt. Morrison).

Etymology: The Korean name, Su-rim-ran is derived from the woodland habitat which it was found.

Habitats: The Underground Forest (Korean name: Jihasanrim) area on Mt. Baekdu has a pine forest comprising

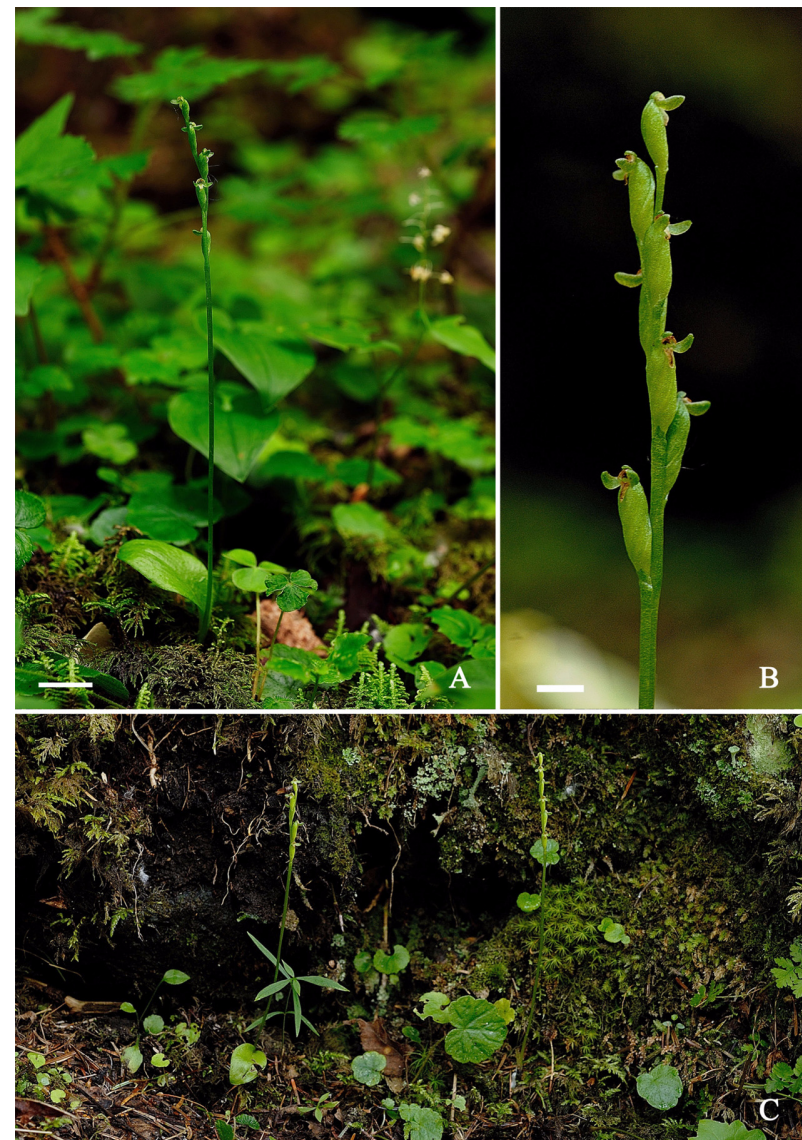

Fig. 2. Photographs of Androcorys pusillus (Ohwi \& Fukuy.) Masam. at the natural habitat in Mt. Baekdu. A. Adult plant, scale bar $5 \mathrm{~mm}$; B. Flower, scale bar $2 \mathrm{~mm}$; C. Habitat.

Larix olgensis, Acer ukurunduense, Picea jezoensis, Abies nephrolepis, etc. (Kim, 2004). The natural habitat of Androcorys pusillus (Ohwi \& Fukuy.) Masam. was found in the woodlands of the Underground Forest area. This species occurs under trees in forests dominated by Larix olgensis, Picea jezoensis, and Abies nephrolepis. The species also occurs with other herbaceous species dominated by Mitella nuda, Linnaea borealis, Oxalis acetosella, and Gymnocarpium jessoense.

\section{Key to Androcorys pusillus and its related taxa.}

1. Sepal margin entire.

2. Lateral sepals pendulous. A. ophioglossoides

2. Lateral sepals spreading.

3. Apex of dorsal sepal obtuse. ……... A. pungioniformis

3. Apex of dorsal sepal apiculate. …………... A. spiralis

1. Sepal margin denticulate.

4. Petals as broad as dorsal sepal. … A. pusillus 수림란

4. Petals narrower than dorsal sepal. ……... A. oxysepalus

This species was listed as a threatened species in IUCN Red 
Data List (IUCN, 2012). With respect to conservation biology, Androcorys pusillus (Ohwi \& Fukuy.) Masam. should be designated as an endangered species, because of its small population of thirty individuals found in Mt. Baekdu.

\section{Acknowledgement}

We are deeply indebted to Seon-Won Suh and Hwa-Jung Suh for their kindly help.

\section{Literature Cited}

Chen, S. C., S. W. Gale and P. J. Cribb. 2009. Androcorys Schlechter. In Flora of China. Vol. 25. Wu, Z.-Y. and P. H. Raven (eds.), Science Press, Beijing and Missouri Botanical Garden Press, St. Louis, USA. Pp. 162-164.

IUCN. 2012. IUCN Red List of Threatened Species. Version 2012.
2. Retrieved Nov. 12, 2012. from http://www.iucnredlist.org. Kim, M. 2004. Korean Endemic Plants. Solkwahak, Seoul. Pp. 237. (in Korean)

Kitamura, S. G. Murata and T. Koyama. 1986. Colored Illustrations of Herbaceous Plants of Japan Vol. III (Monocotyledoneae). Hoikusha, Osaka, Japan. Pp. 23-24. (in Japanese)

Lee, N. S. 2010. Illustrated Flora of Korean Orchids. Ewha Womans University Press, Seoul. Pp. 114-135. (in Korean)

Lee, Y. N. 1991. Flowering Plants on Baekdu Mountain. Hangilsa, Seoul. Pp. 1-39.

Liu, T. S. and H. J. Su. 1978. Orchidaceae. In Flora of Taiwan, Vol. 5. Li, H. L. et al. (eds.), Epoch Publishing Co., Ltd, Taipei, Taiwan. Pp. 873.

Maekawa, F. 1971. The Wild Orchids of Japan in Colour. Seibundoshinkousha, Tokyo, Japan. Pp. 144-145. (in Japanese)

Ohwi, J. 1984. Flora of Japan. Smithsonian Institution, Washington, D. C. Pp. 323-326. 